\title{
Influence of Mineral Fertilization and Zeolite on Soybean Productivity Elements in Climatic Conditions from ARDS Turda
}

\author{
Susana SFECHIS ${ }^{1}$, RoxanaVIDICAN*, Ioan ROTAR, Vlad STOIAN \\ ${ }^{1}$ Faculty of Agriculture, University of Agricultural Sciences and Veterinary Medicine, Calea Manastur \\ Street, No. 3-5, 400372, Cluj-Napoca, Romania; \\ * corresponding author:roxana.vidican@usamvcluj.ro \\ Bulletin USAMV series Agriculture 71(2)/2014 \\ Print ISSN 1843-5246; Electronic ISSN 1843-5386 \\ DOI 10.15835/buasvmcn-agr: 10672
}

\begin{abstract}
Soybean is one of the most important oilseed crop production and forage feed, representing 58\% of total production of oilseeds in the world and $69 \%$ of protein intake from forage. The experience aims assessing the effect of single and combined fertilization with different doses of chemical fertilizers and zeolite, the elements of productivity and microbiological characteristics of soil on nodule number of soybean crop in the climatic conditions from 2013 year. Following the results it is found that fertilization based on equal amounts of urea and zeolite affects positively nitrogen fixing symbiosis. The effect is being stronger than if the fertilization is made by urea, fertilizer complex and zeolite, the recorded differences are large. Soybean production in 2013 specified the largest production increase $1.74 \mathrm{t} /$ ha produced by the variant treated with $50 \mathrm{t} /$ ha urea $+50 \mathrm{t} /$ ha zeolite with no significant differences.
\end{abstract}

Keywords: soybean, rhizobia, faeoziom argic, chemical nitrogen, zeolite.

\section{INTRODUCTION}

Soybean (Glycine max (L.) Merrill) is one of the world's most valuable crops, the plant became known in the current agronomic context, because it is considered that it will help feed the current and future population and contribute to resolving global deficit of protein (Maingate et al., 2006).

Global soybean production increased by $4.6 \%$ annually, from 1961 to 2007 , and reached the present to an annual value of 217,6 millions tonnes. By 2030 the world soybean production is expected to increase at the amount of 371.3 million tonnes (Masuda and Goldsmith, 2009).

Biological nitrogen fixation and nitrogen fertilizers are the main requirement sources of nitrogen for obtaining high yields of soybean crop. However, the antagonism between the concentration of nitrate in the soil solution and the process of nitrogen fixation in the nodules may be a limiting factor for plant growth and development. Along with the antagonism, biological nitrogen fixation activity is conditioned by soil moisture (Purcell et al., 2004),
pH (Parker and Harris, 1977) or the temperature of the root area (Novo Soares et al., 1999).

The productivity potential of soybean crop has declined primarily due to the high sensitivity of soybean plants, physico-chemical conditions, trophicity of the soil and climatic conditions (Takuji Ohyama et al., 2009).

\section{MATERIALS AND METHODS}

The experiments were located at ARDS Turda on faeoziom argic soil, following the latin rectangle method with 4 repetitions, 8 variants containing different doses of fertilizer: zeolite, urea and complex fertilizer: $\mathrm{NP}_{20: 20}: \mathrm{V}_{1}$ - control (untreated); $\mathrm{V}_{2}$ - urea $100 \mathrm{~kg} / \mathrm{ha} ; \mathrm{V}_{3}$ - zeolite $100 \mathrm{~kg} / \mathrm{ha} ; \mathrm{V}_{4}-50$ $\mathrm{kg} / \mathrm{ha}$ urea $+50 \mathrm{~kg} / \mathrm{ha}$ zeolite; $\mathrm{V}_{5}-70 \mathrm{~kg} / \mathrm{ha}$ urea $+30 \mathrm{~kg} /$ ha zeolite; $\mathrm{V}_{6}-50 \mathrm{~kg} / \mathrm{ha} \mathrm{NP} \mathrm{P}_{20: 20}+50 \mathrm{~kg} / \mathrm{ha}$ zeolite; $\mathrm{V}_{7}-75 \mathrm{~kg} / \mathrm{ha} \mathrm{NP}_{20: 20}+25 \mathrm{~kg} /$ ha zeolite; $\mathrm{V}_{8}$ - $75 \mathrm{~kg} /$ ha zeolite $+25 \mathrm{~kg} / \mathrm{ha} \mathrm{NP}_{20: 20}$, the chimical composition of zeolite is clinoptilolite, native from Slovenia; urea and complex fertilizer $\mathrm{NP}_{20: 20}$ are summarized in Tab. 1. 
Tab. 1. The chemical composition of the zeolite, urea and complex $\mathrm{N}_{20}-\mathrm{P}_{20}$

\begin{tabular}{lcccc}
\hline & \multicolumn{4}{c}{ Chemical composition } \\
\hline \multirow{3}{*}{ Zeolie } & $\mathrm{SiO}_{2}$ & $65.00-71.30 \%$ & $\mathrm{Al}_{2} \mathrm{O}_{3}$ & $11.50-13.10 \%$ \\
\cline { 2 - 5 } & $\mathrm{CaO}$ & $2.70-5.20 \%$ & $\mathrm{~K}_{2} \mathrm{O}$ & $2.20-3.40 \%$ \\
\cline { 3 - 5 } & \multirow{2}{*}{$\mathrm{Ne} \mathrm{O}_{3}$} & $0.70-1.90 \%$ & $\mathrm{Na}_{2} \mathrm{O}$ & $0.20-1.30 \%$ \\
\cline { 3 - 5 } & $\mathrm{TiO}_{2}$ & $0.10-0.30 \%$ & & \\
\cline { 3 - 5 } Urea & & min. $46 \%$ & & \multirow{2}{*}{$20 \%$} \\
\hline Complex fertilizer & & $20 \%$ & $\begin{array}{c}\mathrm{P}_{2} \mathrm{O}_{5} \\
\text { total }\end{array}$ \\
$\mathrm{N}_{20}-\mathrm{P}_{20}$ & & &
\end{tabular}

Tab. 2. The climate in the vegetation period Turda in 2013

\begin{tabular}{|c|c|c|c|c|c|c|c|}
\hline \multicolumn{8}{|c|}{ Temperature $\left({ }^{\circ} \mathrm{C}\right)$} \\
\hline Month & IV & $\mathrm{V}$ & VI & VII & VIII & IX & $\mathrm{X}$ \\
\hline Average monthly ${ }^{\circ} \mathrm{C}$ & 12.3 & 16.8 & 19.4 & 20.9 & 22.1 & 13.8 & 11.2 \\
\hline Average 55 years & 9.8 & 14.7 & 17.7 & 19.6 & 19.2 & 14.9 & 9.6 \\
\hline Deviation & +2.5 & +2.1 & $\begin{array}{l}+1.7 \\
\end{array}$ & +1.3 & +2.9 & -1.1 & +1.6 \\
\hline Characterization & hot & hot & warm & warm & hot & cold & warm \\
\hline \multicolumn{8}{|c|}{ Amount of precipitation (mm) } \\
\hline Amount monthly & 53.3 & 79.3 & 86.2 & 37.6 & 44.0 & 57.8 & 67.8 \\
\hline Average 55 years & 44.7 & 67.7 & 84.5 & 76.7 & 55.9 & 40.3 & 32.0 \\
\hline Deviation & +8.6 & +11.6 & $\begin{array}{l}+1.7 \\
\end{array}$ & -39.1 & -11.9 & +17.5 & $\begin{array}{r}+35.8 \\
\end{array}$ \\
\hline Characterization & $\begin{array}{l}\text { less } \\
\text { rainy }\end{array}$ & $\begin{array}{l}\text { less } \\
\text { rainy }\end{array}$ & normal & $\begin{array}{l}\text { excessively } \\
\text { drough }\end{array}$ & drough & $\begin{array}{l}\text { highly } \\
\text { rainy }\end{array}$ & $\begin{array}{l}\text { excessively } \\
\text { rainy }\end{array}$ \\
\hline
\end{tabular}

As biological material was studied the variety Felix created at ARDS Turda, an early variety of soybean maturity group 00 and with features of outstanding quality, suitable for favorable areas of soybean culture in Transylvania, Moldavia and Western Lowland.

Regarding the activity of nitrogen fixing bacteria in the soil determinations were made determinations of the number of nodules/plant in flowering phenological phase, carried out according to the methodology proposed by Hoben Somasegaran in 1985.

This research is in phurphose of assessing the effect of single and combined fertilization with different doses of fertilizers and zeolite and over the potential of installing nitrogen-fixing symbiosis in the form of nodules on the surface of the root system of soybean plants.

Statistical analysis of experimental data was done with statistical software (StatSoft, 2012). For predicting the weather impact in soybean crop produc- tion, based on the interaction between the fertilizers and nitrogen-fixing microorganisms activity it was suggested a formula for calculating the potential of the crop yield.

\section{RESULTS AND DISCUSSIONS}

General evolution of the temperature during vegetation period of the year 2013, followed closely the annual average. There were registered strong deviations from the average amount of rainfall, especially in the second half of the vegetation period (Tab. 2).

Generally the months during the vegetation period were characterized as warm or warmer (Tab. 2), temperature values have changed from the multiannual averages range -1.1 to $+2.9^{\circ} \mathrm{C}$ and pluviometric regime remained close to the normal values between 8.6-11.6 mm exceeding the monthly annual average values.

During July and August of 2013 was drought periods, with heat and low values of relative 
humidity, which indicates a strong midsummer drought affecting the normal growth of soybean plants. A sufficient amount of precipitation has been reached from the end of August, that had a reduced effect on plant growth.

Under normal conditions, soybean plants fix large quantities of nitrogen from the atmosphere because the activity of symbiotic bacteria in the nodules roots.

However, the formation of nodules and nitrogen fixation are very sensitive to the environmental conditions. Therefore, stress, water deficit, the decrease of oxygen in the soil, nutrient deficiency can suppress the formation of nodules and fixation of nitrogen, in addition, can reduce the nitrogen fixing bacteria populations.

In the conditions of 2013, the variation in the number of nodules on soybean roots is within the range of 45 nodules/plant at variant $\mathrm{V}_{2}$ treated with $100 \mathrm{~kg} / \mathrm{ha}$ urea to 97.88 nodules/plant at variant $V_{4}$ treated with $50 \mathrm{~kg} / \mathrm{ha}$ urea $+50 \mathrm{~kg} / \mathrm{ha}$ zeolite (Tab. 3, Fig. 1).

Variant $\mathrm{V}_{3}$ treated with $100 \mathrm{~kg} / \mathrm{ha}$ zeolite has registered significant positive values to variant $\mathrm{V}_{2}$ treated with $100 \mathrm{~kg} / \mathrm{ha}$ urea. Variant $\mathrm{V}_{4}$ treated with $50 \mathrm{~kg} / \mathrm{ha}$ urea $+50 \mathrm{~kg} /$ ha zeolite has

Tab. 3. Comparative analysis of the number of nodules under the effect of the application of differentiated fertilization

\begin{tabular}{|c|c|c|c|c|c|c|c|c|c|}
\hline Variant & & 1 & 2 & 3 & 4 & 5 & 6 & 7 & 8 \\
\hline & Average & 64.00 & 45.00 & 79.88 & 97.88 & 72.25 & 69.75 & 53.38 & 69.75 \\
\hline 1 & 64.00 & & 0.2217 & 0.3049 & $0.0348^{*}$ & 0.5909 & 0.7075 & 0.4896 & 0.7075 \\
\hline 2 & 45.00 & & & 0.0303* & $0.0019 * *$ & 0.0845 & 0.1152 & 0.5853 & 0.1152 \\
\hline 3 & 79.88 & & & & 0.2462 & 0.6192 & 0.5101 & 0.0929 & 0.5101 \\
\hline 4 & 97.88 & & & & & 0.1036 & 0.0756 & $0.0072^{\circ \circ}$ & 0.0756 \\
\hline 5 & 72.25 & & & & & & 0.8703 & 0.2246 & 0.8703 \\
\hline 6 & 69.75 & & & & & & & 0.2903 & 1.0000 \\
\hline 7 & 53.38 & & & & & & & & 0.2903 \\
\hline 8 & 69.75 & & & & & & & & \\
\hline & & & $0.05^{* \circ}$ & $=0.01^{* * \circ \circ}$ & $\mathrm{p}<0.001^{* *}$ & & & & \\
\hline
\end{tabular}

$\mathrm{V}_{1}$ - control (untreated) $; \mathrm{V}_{2}$ - urea $100 \mathrm{~kg} / \mathrm{ha} ; \mathrm{V}_{3}$ - zeolite $100 \mathrm{~kg} / \mathrm{ha} ; \mathrm{V}_{4}-50 \mathrm{~kg} / \mathrm{ha}$ urea $+50 \mathrm{~kg} / \mathrm{ha}$ zeolite; $\mathrm{V}_{5}-70 \mathrm{~kg} / \mathrm{ha}$ urea $+30 \mathrm{~kg} / \mathrm{ha} \mathrm{zeolite} ; \mathrm{V}_{6}-50 \mathrm{~kg} / \mathrm{ha} \mathrm{NP} \mathrm{P}_{20: 20}+50 \mathrm{~kg} / \mathrm{ha}$ zeolite; $\mathrm{V}_{7}-75 \mathrm{~kg} / \mathrm{ha} \mathrm{NP}{ }_{20: 20}+25 \mathrm{~kg} / \mathrm{ha}$ zeolite; $\mathrm{V}_{8}-75 \mathrm{~kg} / \mathrm{ha}$ zeolite $+25 \mathrm{~kg} / \mathrm{ha} \mathrm{NP}_{20: 20}$

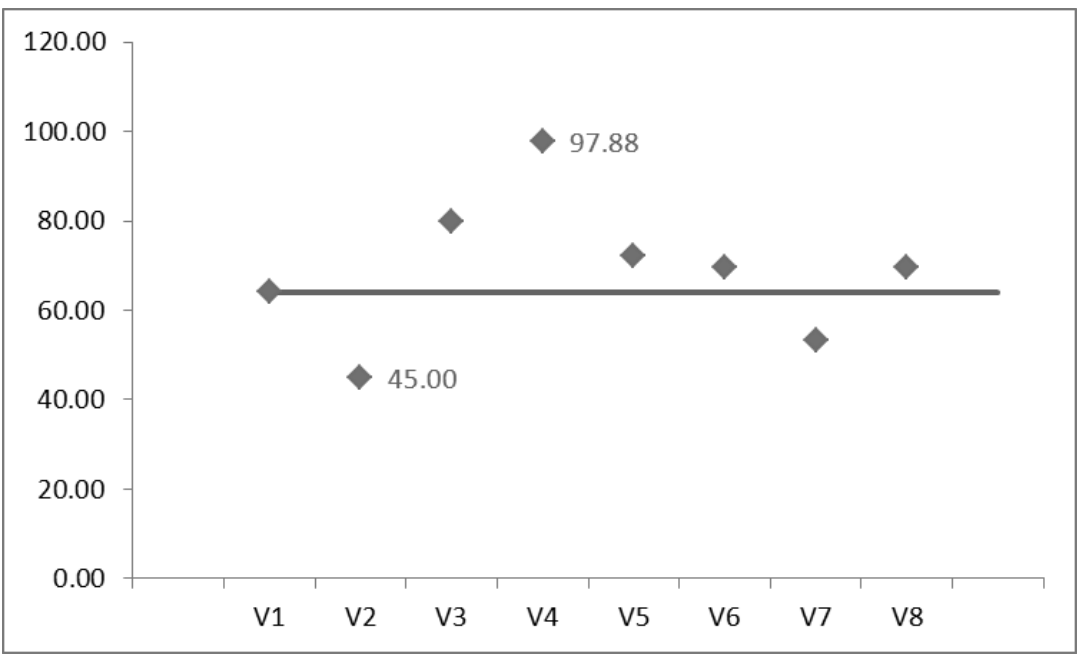

Fig. 1. The variation of the number of nodules under the effect of differential fertilization 
registered significant positive values to the control variant $\mathrm{V}_{1}$ and highly significant positive values to the variant $\mathrm{V}_{2}$ treated with urea $100 \mathrm{~kg} / \mathrm{ha}$ urea. Variant $\mathrm{V}_{7}$ treated with $70 \mathrm{~kg} / \mathrm{ha}$ urea $+30 \mathrm{~kg} / \mathrm{ha}$ zeolite has registered highly significant negative values to the variant $V_{4}$ treated with $50 \mathrm{~kg} / \mathrm{ha}$ urea $+50 \mathrm{~kg} /$ ha zeolite (Tab. 3, Fig. 1).

The presence of numerous active nitrogenfixing nodules on the surface of soybean plant roots can be used as an indicator to highlight the beneficial influences, direct and indirect, that bacteria in the rhizosphere and rizoplan exerts on plants and the complex interrelationships are defined at this level (Gutiérrez-Manero and Ramos-Solano, 2001).

Between full fertilization with urea and complex fertilizer with zeolite are significant differences in the number of nodules (Tab. 3, Fig. 1). This phenomenon can be explain by the amount of available nitrogen for plants, a fertilizer with nitrogen from urea, reducing the occurrence of the symbiosis.

The presence of large numbers of fixing bacteria with solubilized potentially in the rhizosphere of soybean plants can be correlated with a the balanced fertilizer favoring strengthening and formation of nodules on soybean plants, while stimulating the development of nitrogen fixing bacteria (Muntean et al, 2003). Nodules on soybean roots can exert direct effects on atmospheric nitrogen fixation and indirect effect on plant growth by increasing the amount of atmospheric nitrogen fixed.
The most important factors for a high production of soybean culture are nitrogen fixation in the soil and nitrogen absorption of the roots, but simply the nitrogen fixing nodules are often insufficient to support vigorous growth of high yields. However, an abundant fertilizer with nitrogen can reduce the development of nitrogenfixing nodules activity or cause an increase in the formation of luxuriant and poor pods, leading to a decrease in the yield of seeds.

For year 2013, the results indicate an increase in the application of differentiated fertilization influence on not significantly increase soybean crop production. The highest yield was obtained from version $\mathrm{V}_{4}$ treated with $50 \mathrm{~kg} / \mathrm{ha}$ urea $+50 \mathrm{~kg} / \mathrm{ha}$ zeolite, and the lowest yield was obtained from version $\mathrm{V}_{2}$ treated with $100 \mathrm{~kg} / \mathrm{ha}$ urea (Tab. 4, Fig. 2).

Based on the correlation of the results regarding the recorded production during 2013 with the fertilization level and the number of nodules observed, we developed a formula for forecasting the production (equation 1, Fig. 3).

Coefficients are multiplied by factors of nodulation and fertilization have lower values in forecasting equation, indicating the need to integrate the results of several experimental years to obtain more advanced models.

Forecasting equation highlights the low suitability of climatic conditions for the cultivation of soybeans in 2013, both fertilization and microbial activity in the nodule having a reduced action potential (Fig. 3). However, the variants

Tab. 4. Comparative data analysis at the evolution in crop production under the application effect of the differentiated fertilization

\begin{tabular}{|c|c|c|c|c|c|c|c|c|c|}
\hline Variant & & 1 & 2 & 3 & 4 & 5 & 6 & 7 & 8 \\
\hline & Average & 1.73 & 1.44 & 1.51 & 1.74 & 1.57 & 1.69 & 1.59 & 1.59 \\
\hline 1 & 1.73 & & 0.117 & 0.228 & 0.965 & 0.362 & 0.795 & 0.424 & 0.447 \\
\hline 2 & 1.44 & & & 0.699 & 0.107 & 0.491 & 0.185 & 0.423 & 0.401 \\
\hline 3 & 1.51 & & & & 0.212 & 0.761 & 0.340 & 0.676 & 0.647 \\
\hline 4 & 1.74 & & & & & 0.340 & 0.761 & 0.400 & 0.422 \\
\hline 5 & 1.57 & & & & & & 0.512 & 0.909 & 0.877 \\
\hline 6 & 1.69 & & & & & & & 0.587 & 0.615 \\
\hline 7 & 1.59 & & & & & & & & 0.968 \\
\hline 8 & 1.59 & & & & & & & & \\
\hline \multicolumn{10}{|c|}{$\mathrm{p}<0.05^{* \circ} \quad \mathrm{p}<0.01^{* * \circ \circ} \mathrm{p}<0.001^{* * * \circ \circ \circ}$} \\
\hline \multicolumn{10}{|c|}{ 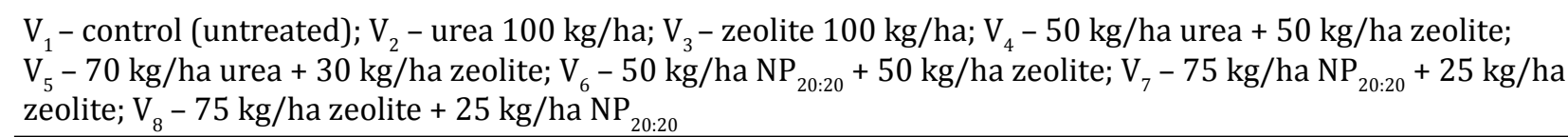 } \\
\hline
\end{tabular}




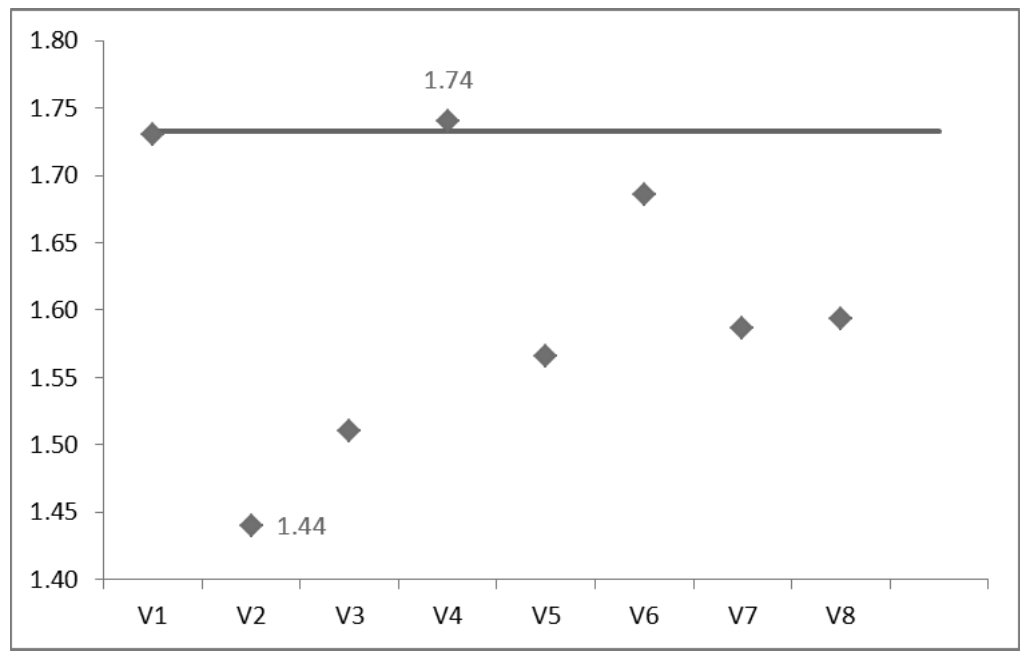

Fig. 2. The variation of crop production under the influence of differentiated fertilization

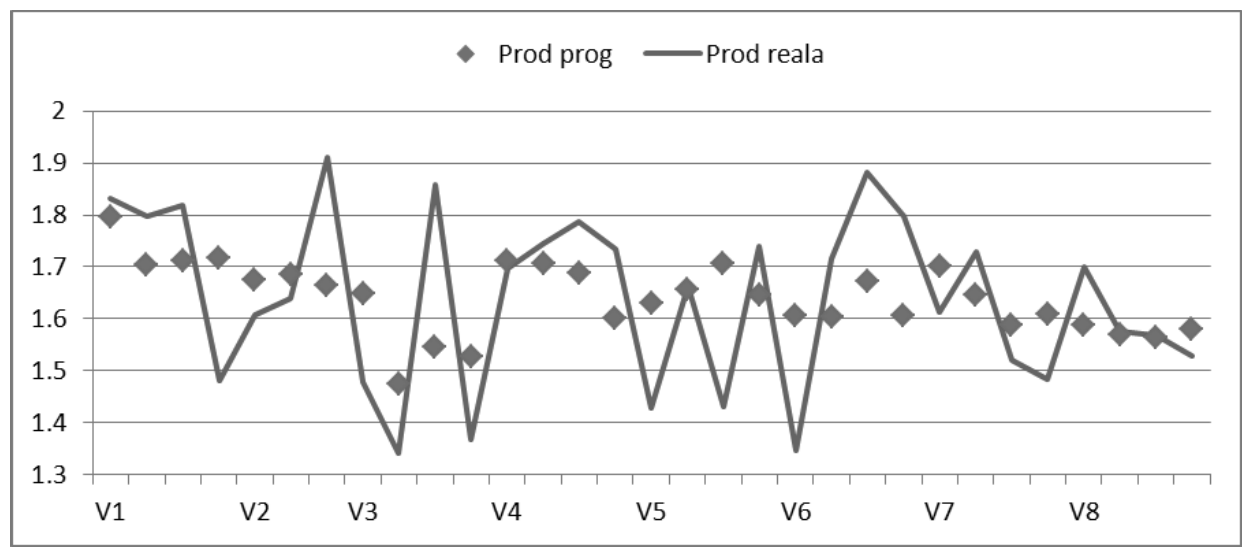

Fig. 3. The potential for crop production forecast based on the number of nodules and fertilizer recipe

Equation 1:

$\operatorname{Prod}\left(\frac{\mathrm{t}}{\mathrm{ha}}\right)=1.6004+0.0021 *$ Nod $-0.0008 * \mathrm{~N}-0.0022 * \mathrm{Z}-0.0006 * \mathrm{P}$

Node - number of nodules plant; $\quad$ Z - zeolite quantity applied $(\mathrm{kg} / \mathrm{ha})$;

$\mathrm{N}$ - amount of nitrogen applied (kg/ha); $\mathrm{P}$ - amount of phosphorus applied (kg/ha).

that were applied moderate doses of chemical fertilizers supplemented with zeolite production forecast falls within reasonable limits to the values recorded in the field.

\section{CONCLUSION}

The climate of 2013 has notallowed expression of the maximum potential of fertilization, obtained yield are quantitatively reduced.
Fertilization simple and combined with zeolite increases the number of nodules variety Felix in 2013.

On the basis of microbial activity and moderate doses of fertilizer one can make realistic forecasts of the crop production.

Acknowledgement. This paper was published under the frame of European Social Found, Human 


\section{Resources Development Operational Programe} 2007-2013, projectno.POSDRU/159/1.5/S/132765.

\section{REFERENCES}

1. Gutiérrez-Mañero F.J., B. Ramos-Solano (2001) The plant-growth-promoting rhizobacteria Bacillus pumilus and Bacillus licheniformis produce high amounts of physiologically active gibberellins. Physiologia Plantarum 111(2): 206-211.

2. Maigi J. M., N.M. Ditonga, C.A. Shisanya, B.Hornetz and G.M. Muluvi (2006). Population levels of indigenous Bradyrhizobia nodulating promiscuous soybean in two kenyan varietyls of the semi-arid and semi-humid agroecological zones. Journal of Agriculture and Rural Development in the Tropics and Subtropics Volume 107, No. 2, pages 149-159.

3. Masuda T., Goldsmith P., D., (2009) World soybean production: area harvested, yield and long-term projections, International Food and Agribusiness Management Review, Vol. 12, Issue, pp. 143-161.

4. Muntean, et all, (2003) Fitotehnie, Ed. USAMV „Ion Ionescu de la Brad" Iaşi, 160-189, 256-276, 303-333.

5. Parker M.B. and Harris H.B, (1977) Yield and leaf nitrogen of nodulating and non-nodulating soybeans as affected by nitrogen and molybdenum, Agron. J. 69, pp. 551-554.
6. Purcell L.C., R. Serraj, T.R. Sinclair and A. De Soybean $\mathrm{N}_{2}$ fixation estimates, ureide concentration, and yield responses to drought (2004) Crop Sci. 44, pp. 484-492.

7. Soares Novo M.C., R.T. Tanaka, H.A.A. Mascarenhas, N. Bortoletto, P.B. Gallo, J.C.V.N. Alves Pereira and A.A. Teixeira Vargas(1999) Nitrogênioe potassio na fixação simbiotica de $\mathrm{N}_{2}$ por soja cultivada no inverno, Scientia Agricola 56 (1) pp. 143-156.

8. Somasegaran P. Hoben J., (1985) Methods in legume Rhizobium technology, University of Hawaii NifTAL *Project and Mircen*, Hawai Institute of Tropical Agriculture and Hunan Resources, College of Tropical Agriculture and Hunan. Resources.

9. STATSOFT, INC. (2012) Electronic Statistics Textbook. Tulsa, OK: StatSoft. WEB: http://www.statsoft.com/ textbook/.

10. Takuji Ohyama, Norikuni Ohtake, Kuni Sueyoshi, Kaushal Tewari, Yoshihiko Takahashi, Sayuri Ito, Toshikazu Nishiwaki, Yoshifumi Nagumo, Satomi Ishii and Takashi Sato (2009). Nitrogen fixation and metabolism in soybean plants Nova Science Publishers, Inc. New York, Chapter 1, pag. 1.

11. Vidican Roxana (2013) The manual application of fertilizers, Risoprint Publishing, Cluj-Napoca.

12. Vidican Roxana (2007) Microbiology, Risoprint Publishing, Cluj-Napoca. 